\title{
Present and Past Status of Indian Agriculture
}

\author{
Avinash sharma ${ }^{2 *}$, Monoj Sutradhar ${ }^{1}$, Sheelawati Monlai ${ }^{2}$ and Nirupa Kumari ${ }^{3}$ \\ ${ }^{1}$ Bidhan Chandra Agricultural University, India
}

${ }^{2}$ Arunachal University of Studies, India

${ }^{3}$ Department of Botany, Patna University, India

Submission: July 28, 2018, Published: September 21, 2018

"Corresponding author: Avinash Sharma, Arunachal University of Studies, National Highway 52 Namsai, Arunachal Pradesh, India; Tel: 9113497113; Email: avinashcau@gmail.com

\begin{abstract}
The background of review has discussed about present positions and past positions of Agriculture. It mentions about area, production, productivity, soils, farm machine \& tools, Gross Domestic Product (GDP), climate, rainfall and water of present and past agriculture. The area and productivity of 2013-14 are higher than area or production of 2015-16. The food grains production of 2013-14 is $12.96 \mathrm{mt}$ higher than food grains production of 2015-16. The $173.65 \mathrm{mha}$ is degraded soil in out of $328.9 \mathrm{mh}$ of geographical areas of India. The soil degradation is reported 53 billion tons annually in India. America developed first farm machines and tools factory in 19th century and they served gas-powered tractors and harvesters to farmers. The farm machine and tools subsidy of 2013-14 is 30\% lesser than farm machine and tools of 2015-16. The carbon dioxide level was $397-416 \mathrm{ppm}$ and is $371 \mathrm{ppm}$ of present period. The temperature was elevated $0.12^{\circ} \mathrm{C}$ and $1.02{ }^{\circ} \mathrm{C}$ or $1-1.4^{\circ} \mathrm{C}$ and $2.23-2.87^{\circ} \mathrm{C}$ are raised into current period. The agriculture GDP of $2013-14$ was $13.9 \%$ and of $2015-16$ is $15.9 \%$. The rainfall efficiency is dependent on precipitation. The rainfall events with precipitation were more than $100 \mathrm{~mm}$ between $1950-2000$ years. The long-term rainfall is below $10 \%$ then the rainfall scarcity is found in the environment. The long-term rainfall of 2013-14 to 2015-16 is below $10 \%$. The ground water utilization has been increased after 1950-51 years. The total utilization of groundwater is 50\% in India. The annual consumption of ground water is 245 billion cubic meters.

Keywords: Area; Production; Productivity; Soils; Farm machine \& tools; Gross domestic product; Climate; Rainfall and Water

Abbreviations: GDP: Gross Domestic Product; KVK: Krishi Vigyana Kendra; ICAR: Indian Council of Agricultural Council; $\mathrm{CO}_{2}$ : Carbon Dioxide; $\mathrm{CH}_{4}$ : Methane; $\mathrm{CFC}$ : Chlorofluro Carbon; $\mathrm{N}_{2} \mathrm{O}$ : Nitrous Oxide; $\mathrm{O}_{3}$ : Ozone
\end{abstract}

\section{Introduction}

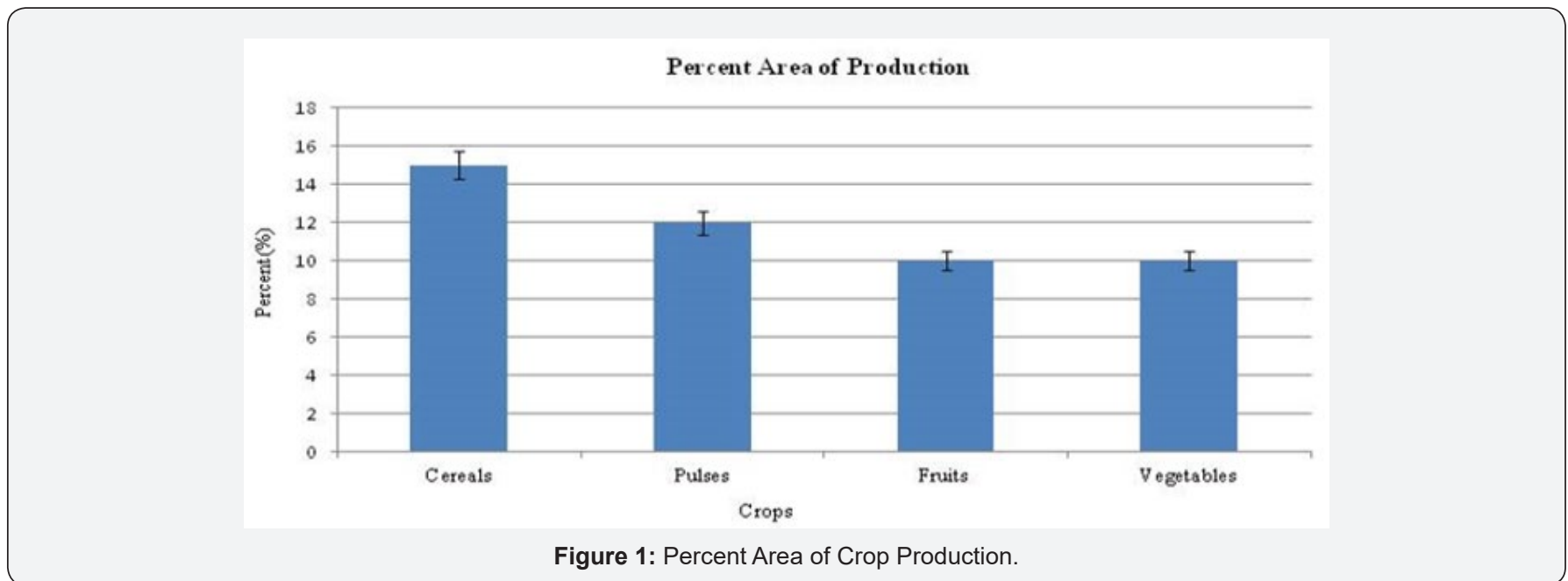

Agriculture is a prominent sector of Indian economy. The agriculture sector of India has occupied almost $47 \%$ of geographical area. Over $70 \%$ of rural household depends on agriculture. The area of production of cereal is $15 \%$, pulses $12 \%$ and fruits or vegetables are below $10 \%$ (Figure 1). The agriculture sector provided $76 \%$ employment in $1950-51$ and provides $52 \%$ employment in 2012-13 because of lower GDP (Figure 2) [1,2]. In 1960 , the growth rate of food grains production was declined $1.40 \%$ in $1949-50$ or $1964-65$ and $2.3 \%$ in $1970-71$ or $1980-81$. The growth rate of food grains production was regained $2.8 \%$ in 
1991-92 (Figure 3). The gross crop area of food grains was $75.54 \%$ in 1970-91 and 63.52\% in 2007-08 (Figure 4). The growth rate of food grains production was declined $1.78 \%$ between $2000-01$ and 2007-08. The 2000-01 and 2007-08 were the critical period to abatement of food grain production [2]. The growth rate of cereals production was $1.7 \%$ in 1990-99. The growth rate of cereals has been declined $-0.2 \%$ in $2000-10$ and the growth rate of cereals production has been declined $0.6 \%$ in 1999-2009. The growth rate of pulse production was $1 \%$ in 1990-99. The growth rate of area has been accounted $3.2 \%$ in $2000-10$. The growth rate of pulse has been abated $2.3 \%$ in 2000-10. The growth rate of vegetable production was $4 \%$ in 1990-99. The growth rate of area has been accounted $2.9 \%$ in 2000-10. The growth rate of vegetable production has been increased $3.3 \%$ in $2000-10$. The growth rate of fruit production was $5.8 \%$ in $1990-99$. The growth rate of area was having been reported 5.3\% in 2000-10. The growth rate of fruit production has been increased $5.7 \%$ in $2000-10$ [3].
The good production of cereals, pulses, fruits and vegetables is obtained with application of fertilizers. The average consumption of fertilizers in India is $128.08 \mathrm{~kg} / \mathrm{ha}$ (State Indian Agriculture, 2015-16). This fertilizer is utilized into arable land. It improves the soil texture and soil structure. The total arable land under fertilizer application is $171 \mathrm{~kg} / \mathrm{ha}$ [4]. Earlier land preparation is completed with indigenous country plough but this tool is not prepared light soils. The sophisticated machine and tools are provided aerated and well quality soils. The total utilization of farm machine and tools in harvesting or threshing activity is $60 \%-70 \%$ and in irrigation is $37 \%$ (Figure 5) [5]. The ground water efficiency was $70-80 \%$ in $1950-51$ and the canal efficiency was $25-45 \%$ in $1950-51$. The net cultivable land of is $143.6 \mathrm{mha}$ in which $42 \mathrm{mha}$ is irrigated by ground water and $22 \mathrm{mha}$ is irrigated by canals. The ground water application has been increased for irrigation in present period.
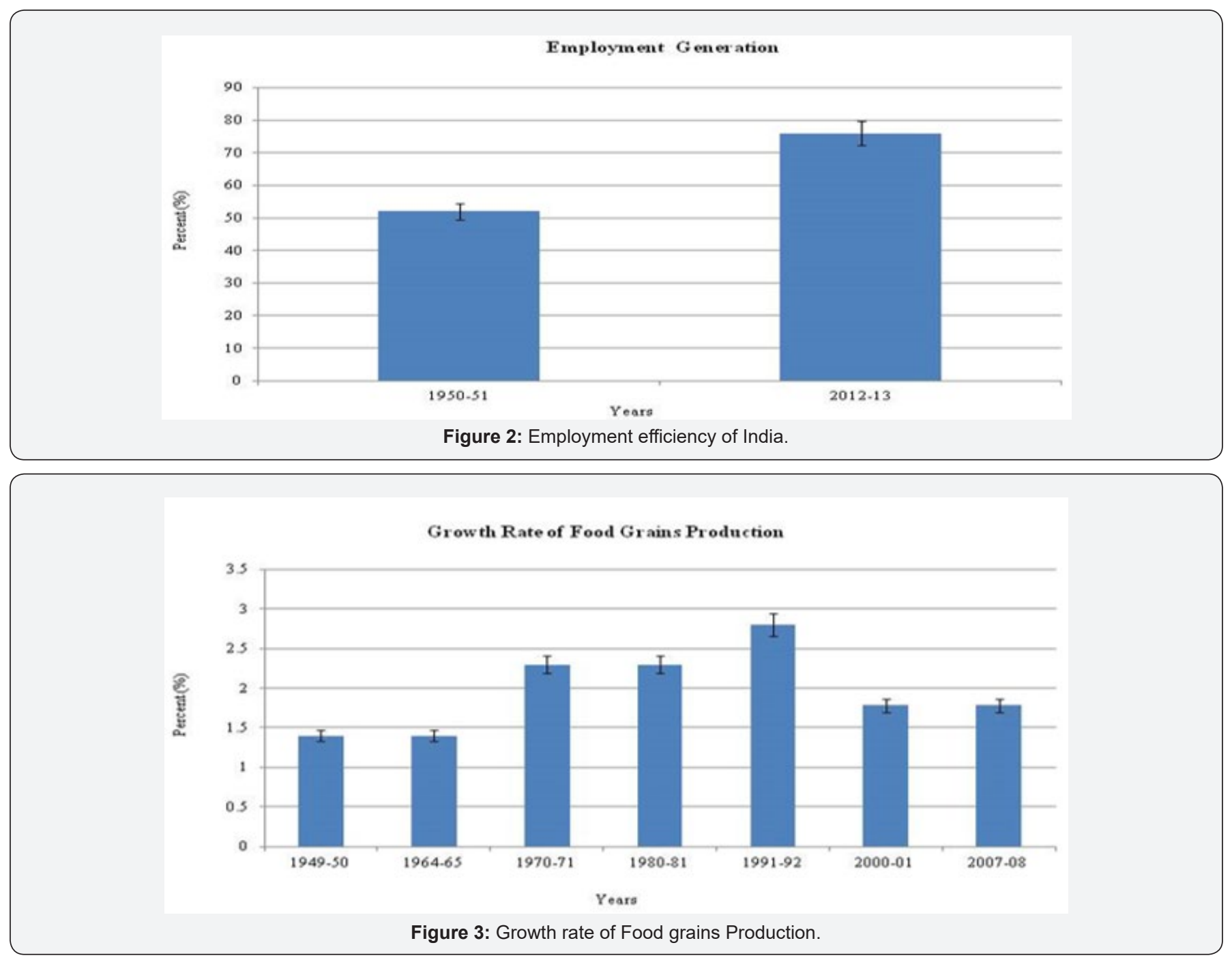

The agricultural inputs are fulfill the requirement of human but some of the factors like overconsumption of fertilizers, overconsumption of pesticides and overexploitation of land are declined a production and productivity of field crops every year. The soil profile temperature tardily increases every year that abate the activity of organic matter and is increasing soil pH, alkali soil and hard soil. It abates area of land and types of soil every year. The increased percentage of atmospheric gases has disturbed ambient temperature, biogeochemical cycle, climate and weather. It imbalances plant ecology and ecosystem every year. 
The central government and the state government have initiated I am highlighting about present and past performance of Indian several agricultural schemes and projects. With this background, agriculture with following factors i.e.
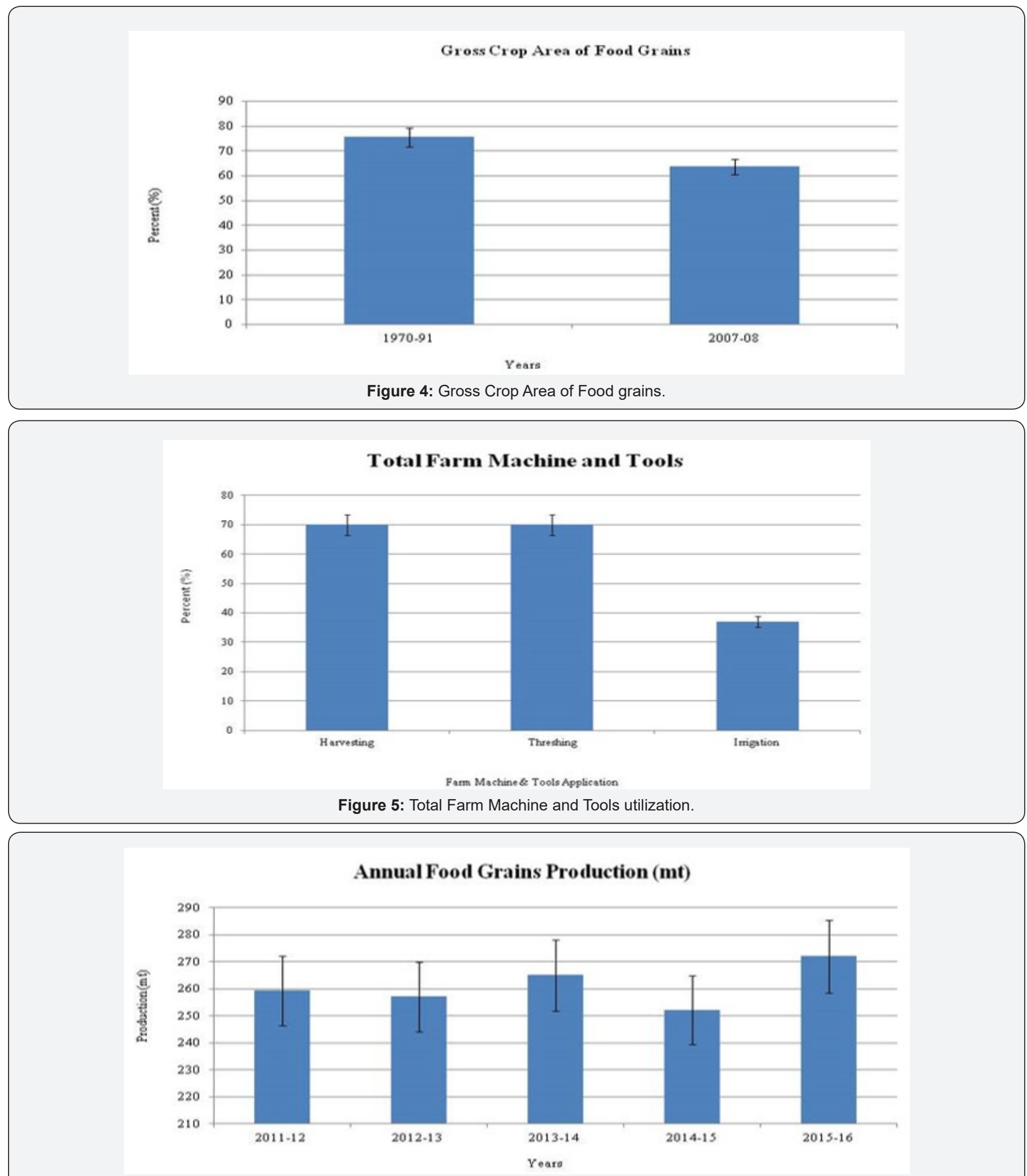

Figure 6: Annual Food Grains Production.

\section{Area, production and productivity}

The production is fundamental stages of Indian season. It provides food security of each nation. It fulfills the nutrient, nutrient deficiency and daily food of human. It is a backbone of Indian economy. It promotes export and import of agricultural raw materials. It also participates by private companies and our 
diligent or competent Indian farmers that shares revenue to the nation. The highest cultivation of crop is estimated by the state level, the national level and the international level every year. The food grains production and major crops production are declining each year. The food grains production has been recorded 259.32 million tonnes in 2011-12 and 257.13 in 2012-13. The total food grains production has been reported 265.04 million tonnes in 2013-14, 252.68 million tonnes in 2014-15, 272 million tonnes in 2015-16 (Figure 6) [5-7].

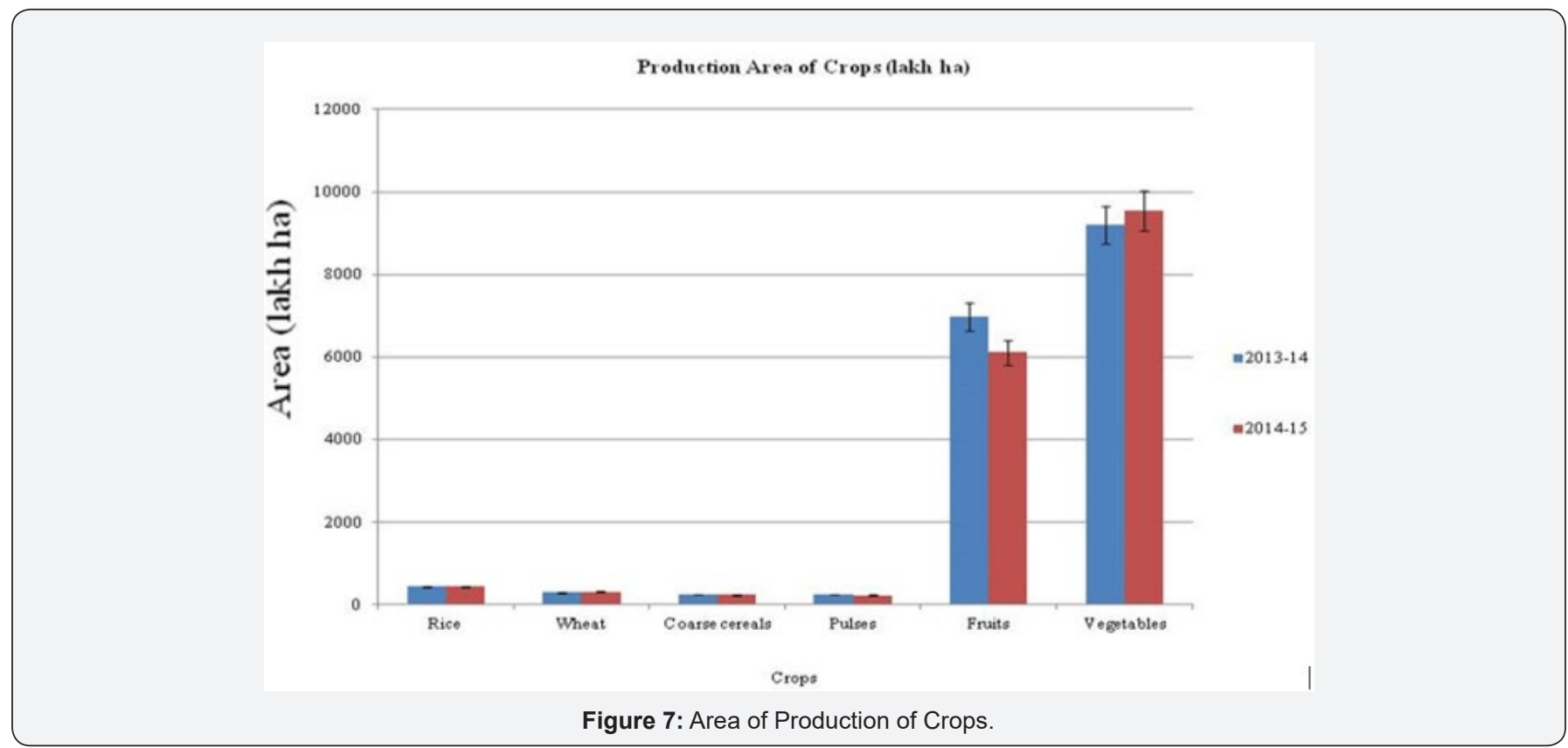

The area of production of rice was 441.36 lakh ha in 2013-14 and 438.56 lakh ha in 2014-15. The area of production of rice was declined 28 lakh ha in 2014-15. The area of production of wheat was 304.73 lakh ha in 2013-14 and 309.69 lakh ha in 2014-15. The area of production of wheat was increased 4.09 lakh ha in 201415. The area of production of coarse cereals was 252.20 lakh ha in 2013-14 and 241.49 lakh ha in 2014-15. The area of production of coarse cereals was abated 10.71 lakh ha in 2014-15. The area of production of pulses was 252.13 lakh ha in 2013-14 and 230.98 lakh ha in 2014-15. The area of production of pulses was abated 21.15 lakh ha in 2014-15. The area of production of fruits was 6982 lakh ha in 2013-14 and 6110 lakh ha in 2014-15. The area of production of fruits was declined 872 lakh ha in 2014-15. The area of production of vegetables was 9205 lakh ha in 2012-13 and 9542 lakh ha in 2014-15 (Figure 7). The area of production of vegetables was abated 337 lakh ha in 2014-15 (Figure 8) (Annual Report 2013-14, and Annual Report 2014-15).

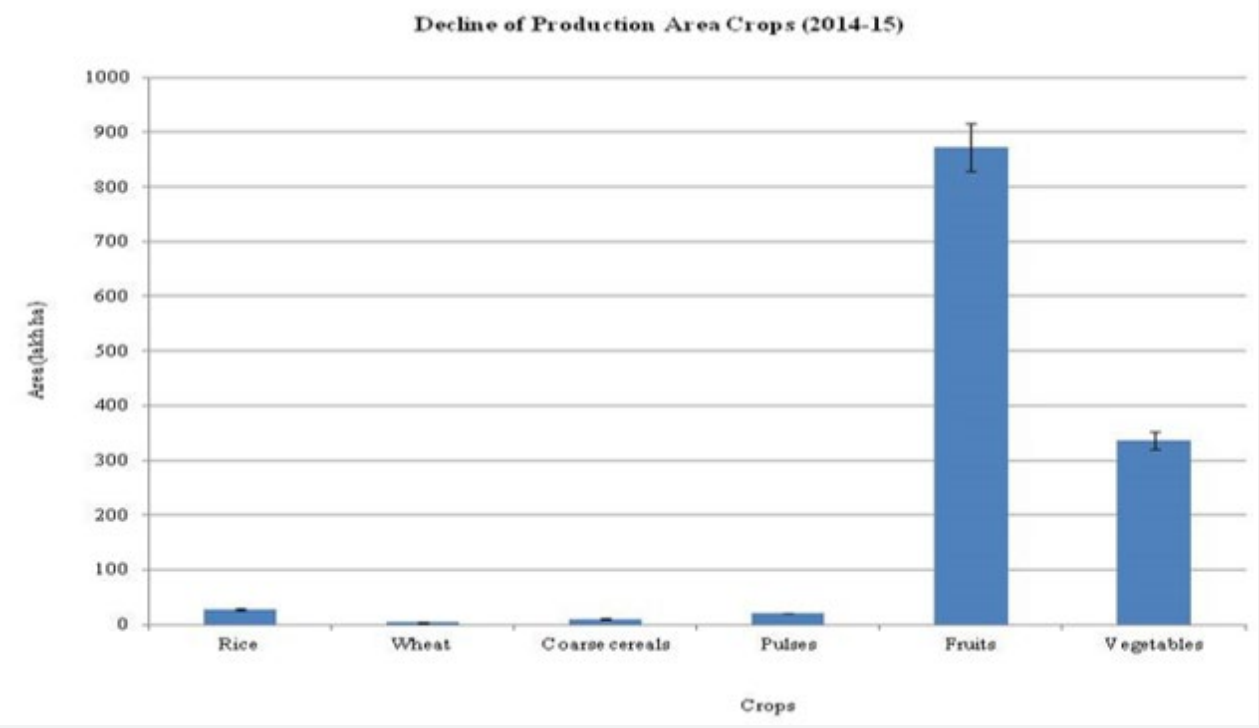

Figure 8: Abatement of Production Area of Crops. 


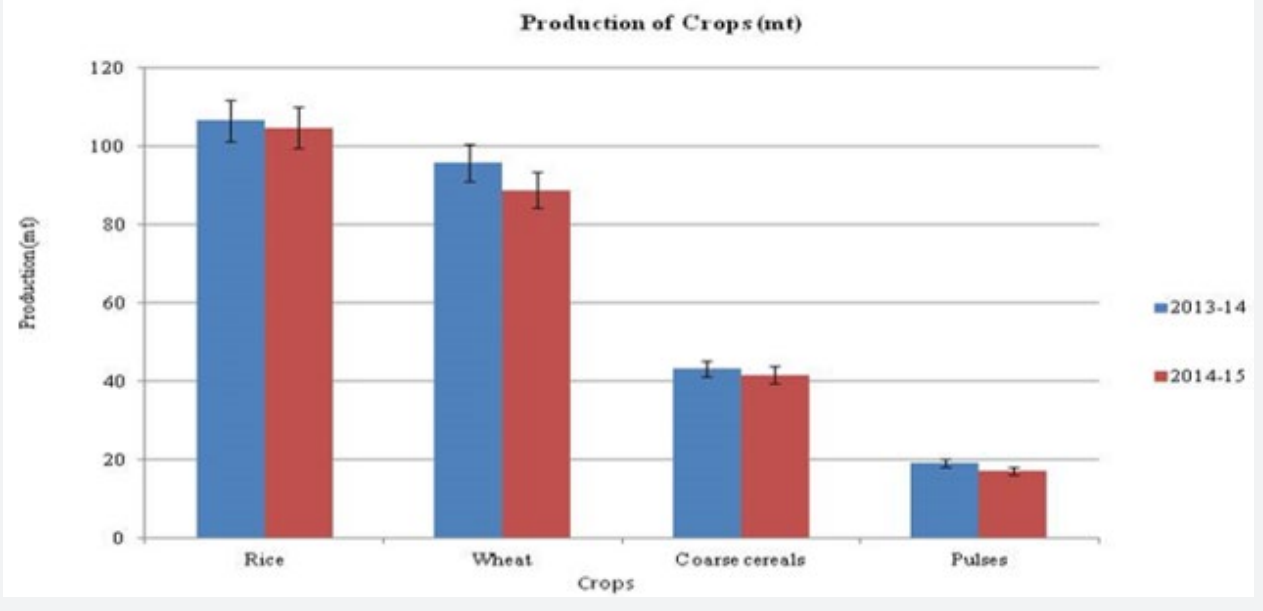

Figure 9: Production of Crops.

The production of rice was 106.65 million tonnes in 2013-14 and 104.80 million tonnes in 2014-15. The production of rice was declined 1.85 million tonnes in 2014-15. The production of wheat was 95.85 million tonnes in 2013-14 and 88.94 million tonnes in 2014-15. The production of wheat was abated 6.91 million tonnes in 2014-2015. The production of coarse cereals was 43.29 million tonnes in 2013-14 and 41.75 million tonnes in 2014-15. The production of coarse cereals was declined 1.54 million tonnes in 2014-15. The production of pulse was 19.25 million tonnes in 2013-14 and 17.20 million tonnes in 2014-15 (Figure 9). The production of pulse was declined 2.05 million tonnes in 2014-15. The production of fruits was 77701 million tonnes in 2012-13 and 88602 million tonnes in 2014-15. The production of fruits was decreased 8901 million tonnes in 2014-15. The production of vegetables was 159511 million tonnes in 2012-13 and 169478 million tonnes in 2014-15. The production of vegetable was decreased 9967 million tonnes in 2014-15 (Figure 10) [6,7].

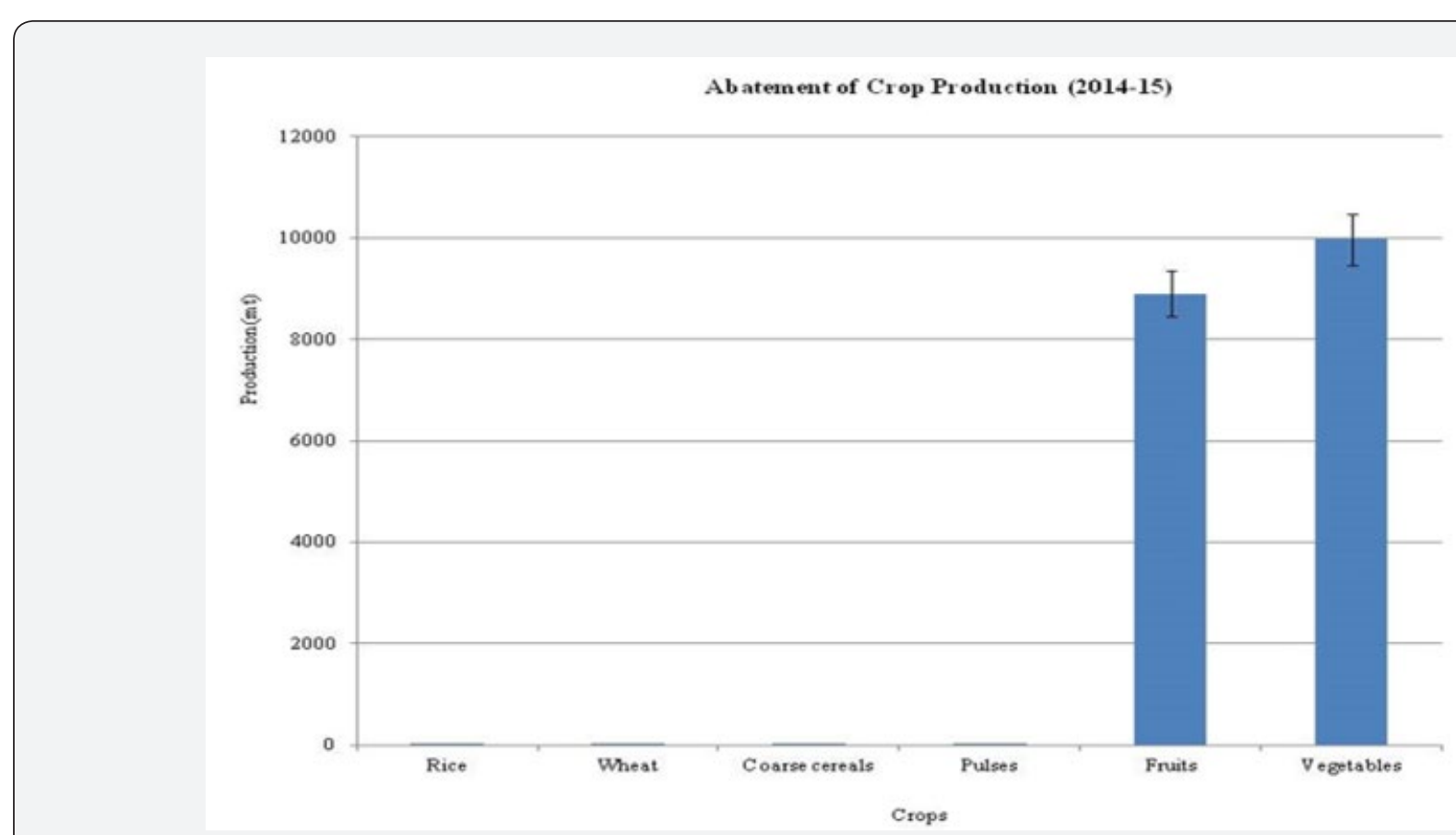

Figure 10: Decline of Production of Crops.

The productivity of rice was $2416 \mathrm{~kg} / \mathrm{ha}$ in $2013-14$ and $2390 \mathrm{~kg} / \mathrm{ha}$ in 2014-15. The productivity of rice was decreased $26 \mathrm{~kg} / \mathrm{ha}$ in $2014-15$. The productivity of wheat was $3145 \mathrm{~kg} / \mathrm{ha}$ in $2013-14$ and $2872 \mathrm{~kg} / \mathrm{ha}$ in $2014-15$. The productivity of wheat was decreased $273 \mathrm{~kg} / \mathrm{ha}$ in $2014-15$. The productivity of coarse cereals was $1717 \mathrm{~kg} / \mathrm{ha}$ in $2013-14$ and $1729 \mathrm{~kg} / \mathrm{ha}$ in $2014-15$ The productivity of coarse cereals was increased $12 \mathrm{~kg} / \mathrm{ha}$ in 2014 15 . The productivity of pulses was $0.764 \mathrm{~kg} / \mathrm{ha}$ in $2013-14$ and $0.744 \mathrm{~kg} / \mathrm{ha}$ in $2014-15$. The productivity of pulses was decreased $0.02 \mathrm{~kg} / \mathrm{ha}$ in $2014-2015$. The productivity of fruits was $1.130 \mathrm{~kg} /$ 
ha in $2013-14$ and $1.417 \mathrm{~kg} /$ ha in $2014-15$. The productivity of fruits was increased $0.287 \mathrm{~kg} / \mathrm{ha}$ in $2014-15$. The productivity of vegetables was $175.9 \mathrm{~kg} / \mathrm{ha}$ in $2012-13$ and $177.6 \mathrm{~kg} / \mathrm{ha}$ in $2014-$
15 (Figure 11). The productivity of vegetables was increased $1.7 \mathrm{~kg} / \mathrm{ha}$ in 2014-15 (Figure 12) [6,7].

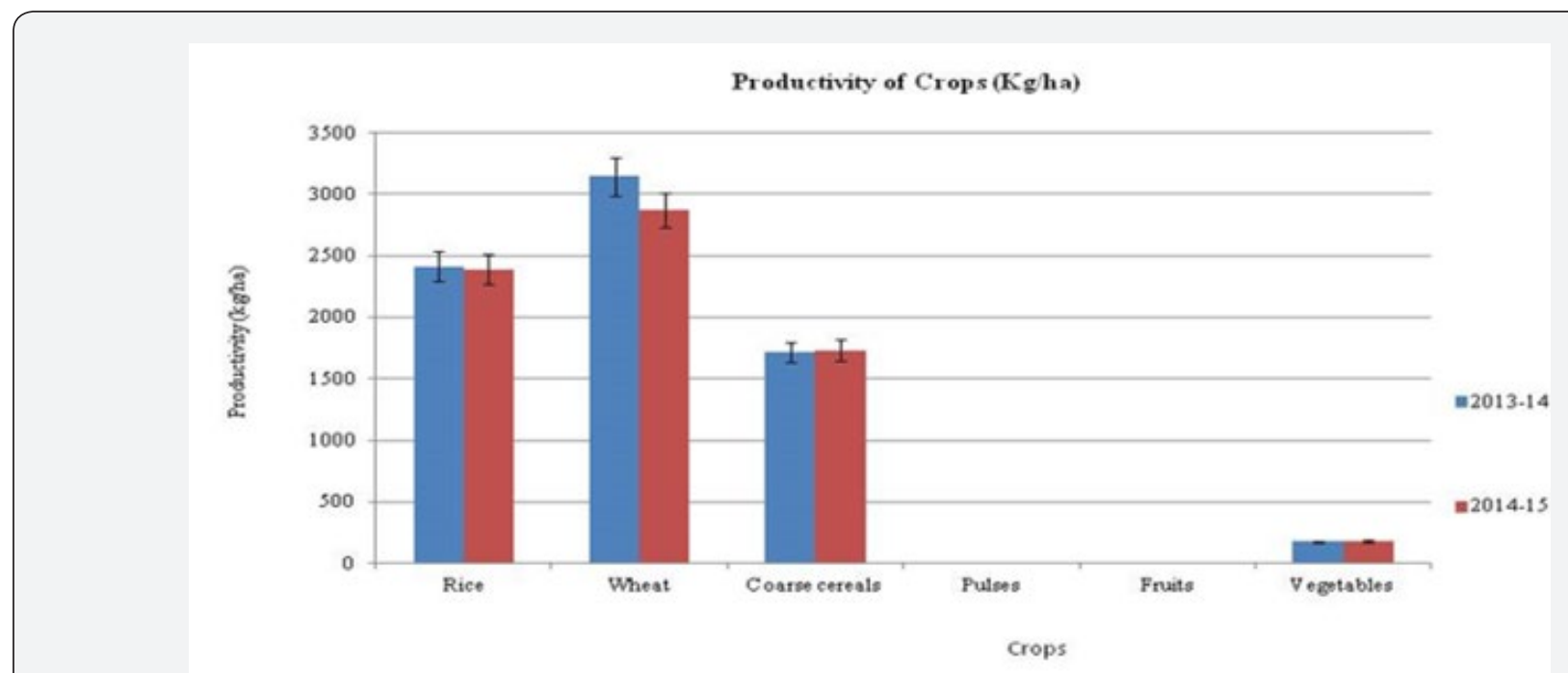

Figure 11: Productivity of crops.

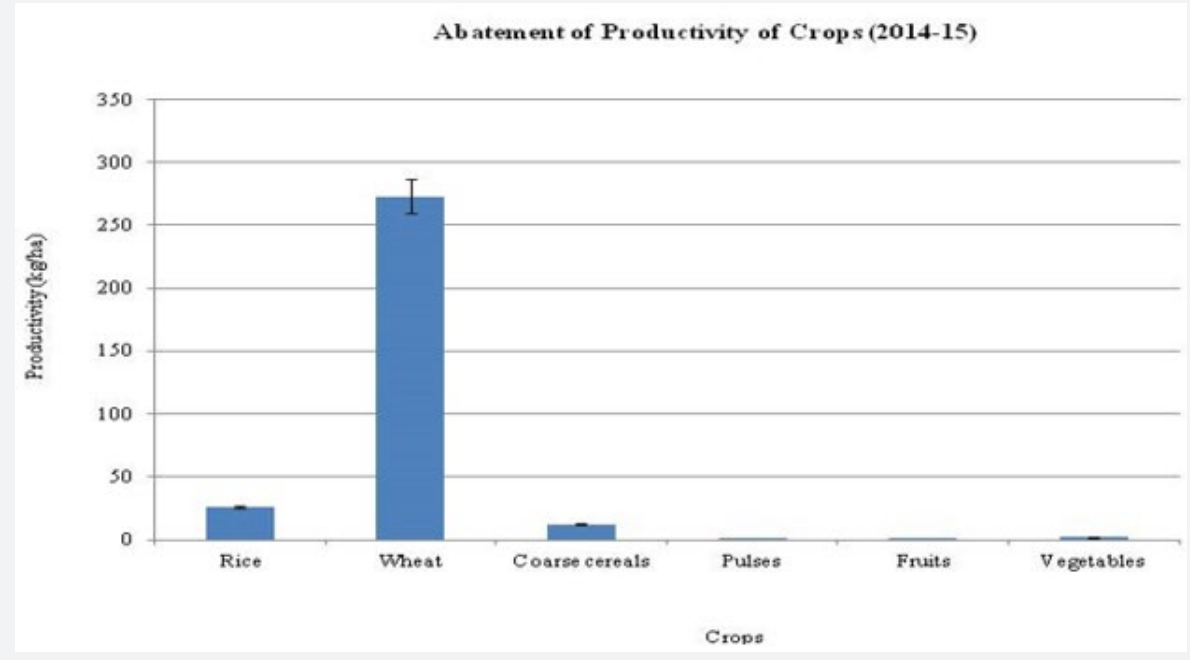

Figure 12: Decreased Crop Productivity.

The food grains and the major crops area, production and productivity are decreased due to overexploitation of fertilizer, improper advent of season or monsoon, overexploitation of land. The metropolis people are shifting toward countryside for livelihood and business that transforms agricultural land into infrastructure land. A man is bearer of agricultural land but his present generation is not aim into agricultural profession. This will reduce an experienced and skilled manpower into upcoming period. The farmer is receiving irregular benefit of agricultural schemes and projects. The commercial bank and the cooperative bank are not passes agriculture loan appropriate manner of Indian farmers. The extension and the awareness programme of media, private companies and Krishi Vigyana Kendra (KVK) are less to crop session.

\section{Soils}

Soil is an abiotic ecosystem that provide abode to organisms. Soil provide habitat to flora, fauna and human. The lower plants and the higher plants are offer security of soil. The human interaction has disturbed the physical, the chemical and the biological activity of soil. Deforestation, improper drainage, overgrazing of animals, excavation of soil to building construction, soil mining prepares roads, railway tracks, private institution, government institution, gowdons, industries, factories, multistorage building are devasted the soil structure, soil texture, physical property and chemical property of soil. The unrecomended dose of agrochemicals like fertilizers, pesticide and herbicide has been retarding or destroying every year physical or chemical action and soil fertility. This is caused land degradation, soil erosion, saline soil, alkali soil, sodic soil, hard soil and marshy soil every year. 


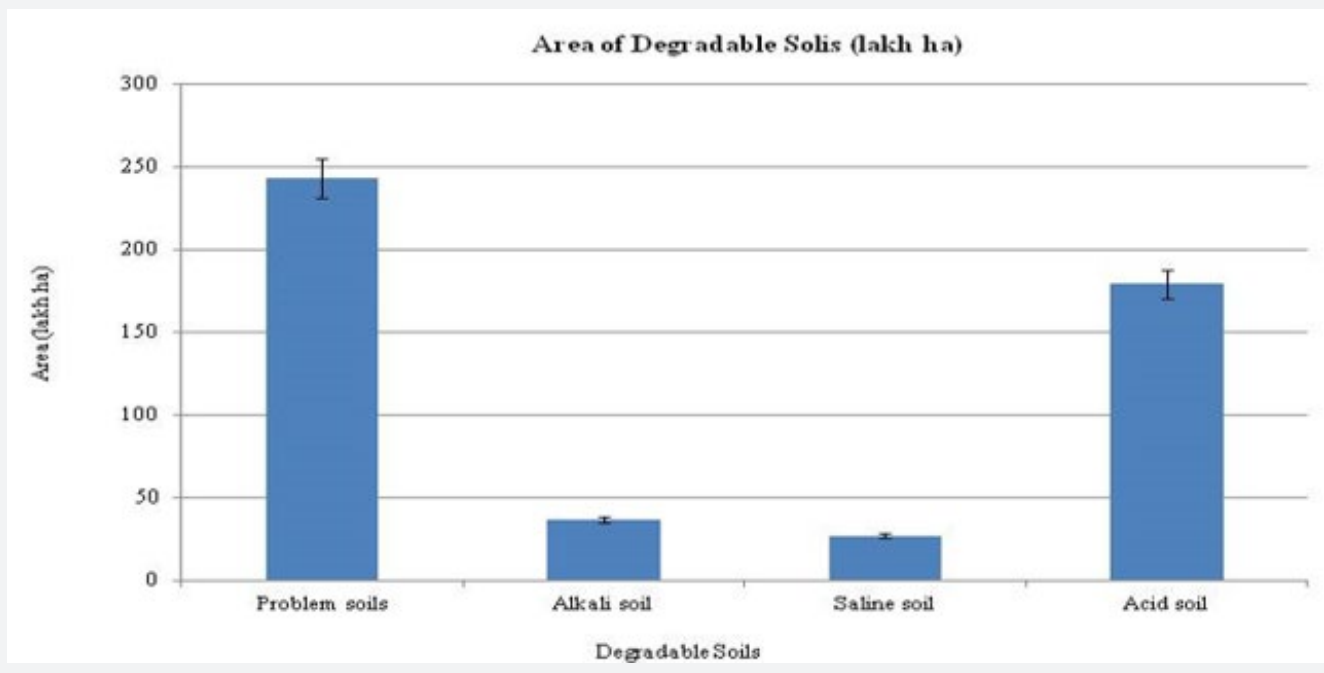

Figure 13: Area of Degradable Soils.

The geographical area of India is $328.9 \mathrm{mha}$ in which 173.65mha are degraded soils [8]. Nellemann et al. [9], reported that every year 2-5mha new degraded land is added into this category. This translates into a loss of nearly 10ha good land per minute to various processes of degradation. The pesticide is recommended into the soil then $1 \%$ pesticide is provide activity in the soil and the remaining pesticide is persist on the soil every year that causes various processes of degradation [10]. The $105 \mathrm{mha}$ of degraded farm land out of total $142 \mathrm{mha}$ net sown area was recorded in Indian farm house [10]. As per Indian Council of Agricultural Council (ICAR) area under problem soil increased from 220 lakh ha (2005) to 243 lakh ha (2010), comprising of alkali soil 37 lakh ha, saline soil including coastal area account for 27lakh ha and acid soil 179 lakh ha (Figure 13) [11]. The ministry of agriculture stated that about 5.3 billion tonnes of soil degraded annually. All these activities are due to imbalance use of agrochemicals into soil every year. The imbalance application of urea has been found more into another fertilizer. This imbalance application was observed in the state of Punjab, Haryana and Uttar Pradesh [5]. The imbalance use of fertilizers is due to lack of awareness about kind of fertilizers; the price of urea is controlled by the government while Potassium and Phosphorus fertilizers were decontrolled in 1992; the central government has allocated more subsidy for fertilizers; the pesticide is monitored by the ministry of chemical and fertilizers and its application is administered by the ministry of agriculture. The ministry of chemical and fertilizers has allocated subsidy; Soil extension programme like soil management programme, demonstration of agrochemical application are conducted less at distant villages and blocks.

\section{Farm machine and tools}

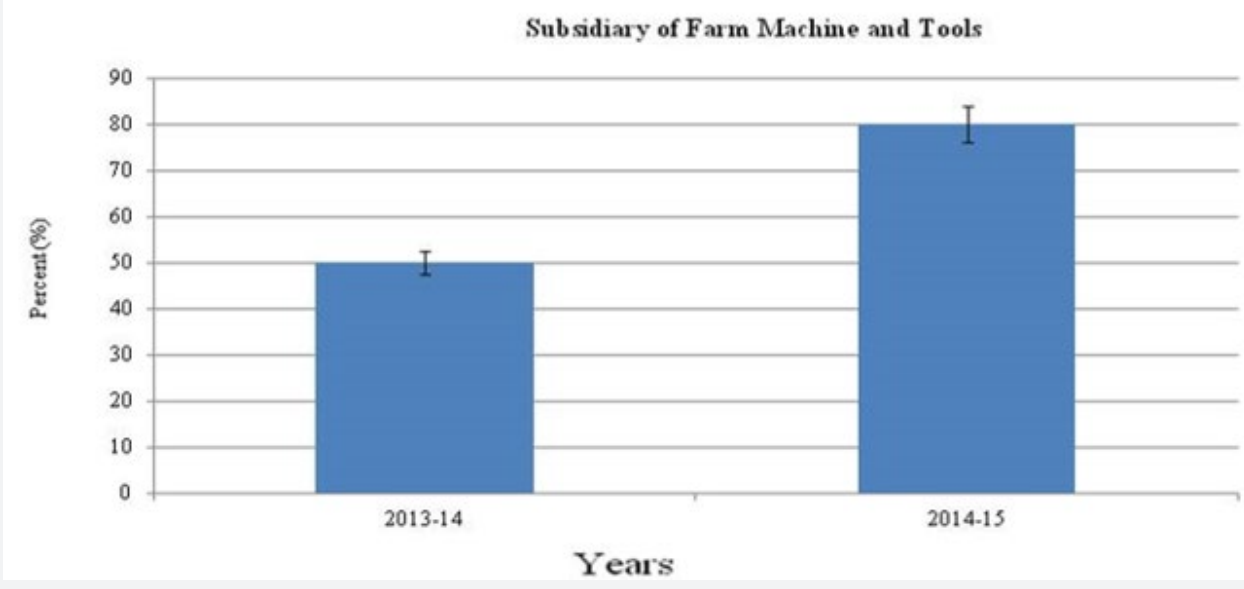

Figure 14: Recession of Farm machine and Tools.

Farm machine and tools are primary input of agriculture. It is applied into both agriculture sessions. It reduces time consumption, cost of cultivation and progresses production, productivity of agricultural crops. The West America was converged with continent in 1801-1900 years. The American farmers and the stockman were settled into the continent. The 
nation was weak and did not establish industry in 1801. The country had established first farm implement and machinery in 1900. The factory had supplied sophisticated machines and tools of the new agriculture. The Internal Combustion Engine was invented in 19th century. It developed gas powered tractors and harvesters. This powerful machine was replaced animals, ploughmen, knives and scythes. The farmers were adopted farm machines and tools in the mid 1900 year [12].

The ministry of agriculture had allocated tractors, power tillers, and combine harvesters to state of Punjab or Haryana under RKVY, NFSM, NHM and TMOOP in 2013-14. The ministry of agriculture has been distributed farm machine and tools like rotavator, maize harvesting combine, paddy happy seeder, DSR drill cum planter, laser land leveler, seed drill/ zero drill/ spatial zero till drill, DSR drill cum planter, sub soiler, power operated spray pumps, battery powered sprayers, tractor operated hydraulic sprayers, hydraulic plough/ mould board plough, Multicrop thresher, maize sheller, mechanical cotton pickers, cotton cleaner to state of Punjab, Haryana and Western Uttar Pradesh under RKVY project They trained 6773 farmers about farm machine and tools [7]. The farmers are utilized more tilling tool, spreading of seed fertilizer tool, harvesting \& threshing machine. These facilities will abate time efficiency, labour costs, manpower and loss of inputs.

The government had disclosed $25-50 \%$ subsidy to farm machine and tools in 2013-14 and 80\% subsidy to farm machine and tools in 2014-15 (Figure 14). These benefits of subsidy are received by large farmers not by marginal and small farmers due to shortage of mortgage. Most of the village farmers are not aware about farm machine and tools subsidy. The information of organized bank and another government institution are drive less into block or villages. These are impacts on young farmers, production, productivity and income doubling of farmers in present agriculture.

\section{Gross domestic product (GDP)}

Annual Agriculture GDP of India

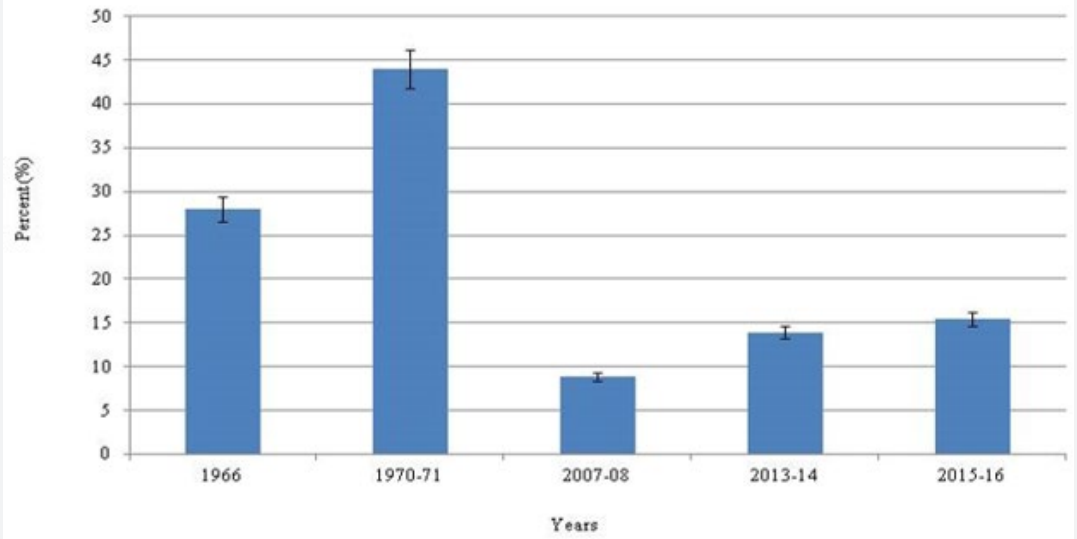

Figure 15: Annual Gross Domestic Product (GDP) of Agriculture.

Agriculture was paramount sector after post-independence. It forecasted the highest GDP among another sector. When two continued droughts were incurred in India during 1966. The Indian farmers had produced 72 million tonnes food grains in 1966. This successful was achieved due to ample water and land resource for agriculture use. The agriculture GDP was grown 3\% per annum. That's why the agriculture GDP of India was $28 \%$ in 1966 [13] and increases 44\% GDP in 1970-71 (Figure 15) [14].

All food crops, oilseeds, fiber, condiment \& spices, fruits and vegetables are sub-sector of agriculture that provides contribution into agriculture GDP. This sub-sector had been provided $78 \%$ share in 1960-61 but it had been declined 70\% share in 1990-91. The shares of cereals $26.6 \%$, pulses $4 \%$, oilseeds $6.7 \%$, fruits \& vegetables $13.6 \%$, Livestock $23.9 \%$, fisheries $3.9 \%$, fibers $2.9 \%$, condiment \& spices $2.6 \%$, crop sector $72.3 \%$ were reported in 1993-94 [14].

The agriculture GDP was reviewed 8.9\% in 2007-08 (Figure 15) (Review of Economy, 2007-08). The shares of subsector cereals $21.7 \%$, Pulses $3 \%$, Oilseeds $5.8 \%$, fruits \& vegetables $16.9 \%$, livestock $26.1 \%$, fisheries $4.4 \%$, fibers $3.6 \%$, condiments \& spices $3.1 \%$ and crop sector $69.5 \%$ were reported in $2007-08$. The share of agriculture imports and exports were declined in 200910. The growth rate was declined $5.8 \%$ from $2007-08$ to $0.8 \%$ in 2009-10. This period was the critical phase of agriculture that agriculture and allied sectors contributed 14.9\% GDP in 2009-10 [14].

The GDP of agriculture and allied sectors was $13.9 \%$ with constant price in 2013-14 (Figure 15). The growth rate was 4.6\% [6]. The shares of subsector $12.5 \%$ livestock, $1.5 \%$ forestry, $1.4 \%$ fisheries, [15] $27 \%$ cereals, $23 \%$ fruits \& vegetables and $9 \%$ oilseeds were contributed in 2013-14 [16]. The current agriculture GDP is $15.4 \%$ with constant prices in $2015-16$ (Figure 15) (State of agriculture in India, 2017). The shares of forestry/fisheries/ livestock produce is above $5 \%$ from last year, food grains is declines $0.5 \%$ from last year, oilseeds is abate $4.1 \%$ from last year and fruits \& vegetables is increase $0.6 \%$ from last year [16]. The 
present agriculture GDP is declining due to overconsumption of agrochemicals, overexploitation of land, confinement of irrigation coverage, agriculture research and extension are not competent to farmers welfare, price policies is not favorable to producers, abatement of agriculture exports, transition of climate \& weather, reduction of employment, industrialization, urbanization, reduction of activity of media, agriculture department, research centers, directorates to remote block \& villages, non-uniform distribution of agriculture policy and scheme to distant farmers. This aspect will impact on future agriculture GDP.

\section{Climate}

Climate is paramount physical factor of crop production and productivity. The mean annual temperature was uniform variable over the period of 1960-99 years [17]. The mean annual temperature was evaluated $0.6^{\circ} \mathrm{C}-0.8^{\circ} \mathrm{C}$ from $1850-2010$ years in India [17]. The global temperature was raised during 20th century. The content level of green house gases like carbon dioxide (CO2), methane (CH4), chlorofluro carbon (CFC), nitrous oxide (N2O) and ozone (03) had been increased the ambient temperature of environment. It had reduced a rainfall, crop production, crop productivity [18-20]. The carbon dioxide concentration was steady state at $280 \mathrm{ppm}$ till the preindustrial period (1850). The carbon dioxide concentration rate is eluviating 1.5\%-1.8\% in atmosphere each year. This carbon dioxide concentration rate has suddenly increased temperature of atmosphere. This carbon dioxide concentration is likely to be doubled by the end of $21 \mathrm{st}$ century. It impacts on crop production, productivity, water use, photosynthesis rate and sugar accumulation [21].

The annual mean temperature had been raised $0.56{ }^{\circ} \mathrm{C}$ in India after the end of 2007 year. The mean winter temperature was increased $0.7{ }^{\circ} \mathrm{C}$ after end of 2007 year. The temperature rate was hastened in past years. The temperature rate from 19712007 years was raised $0.2{ }^{\circ} \mathrm{C}$ at every 10 years. The minimum temperature was transformed into maximum temperature. The all India maximum temperature was increased by $1.02{ }^{\circ} \mathrm{C}$ while minimum temperature was increased by $0.12^{\circ} \mathrm{C}$ [17]. It effects the crop production and productivity when crop temperature is more than $34^{\circ} \mathrm{C}[17]$.

It is estimated that carbon dioxide level will increase to 397 416ppm by 2010 year from the present carbon dioxide level of $371 \mathrm{ppm}$ and this would further increase by 607-755ppm by 2070 year. They projected between $1-1.4{ }^{\circ} \mathrm{C}$ and $2.23-2.87{ }^{\circ} \mathrm{C}$ area average annual mean warming by 2020 year \& 2050 year respectively. Comparatively, increase in temperature is projected to be more in Rabi than in Kharif crop growing season. A large uncertainty is associated with projected Rabi rainfall than Kharif rainfall in 2050 year [22]. This variation of temperature is effect on production, productivity of Kharif and Rabi crops in future era.

\section{Rainfall}

Rainfall is paramount abiotic factor of crop ecosystem. It maintains stability of atmosphere and environment physical factor and provides water or soluble nutrient to agricultural crops. The rainfall activity is dependent on precipitation. The rainfall activity was high when rainfall events with precipitation were higher than $100 \mathrm{~mm}$ in 1950-2000 years [23]. The long term rainfall was $10 \%$ then the frequency of rainfall was high and long term rainfall is below $10 \%$ then the scarcity of rainfall was found in the surrounding. The deficient rainfall was found in 1966, 1972, 1974, 1979, 1989, and 1987 years. The normal or excess rainfall was reported in 1970, 1975, 1978, 1983 and 1988 years. The deficient rainfall and the normal or excess rainfall were declined food grain production [24].

The water availability had been declined during 18th, 19th and 20th century. This period had been announced drought years because of scarcity of rainfall. 10 droughts were observed between 1950-1989 years. 5 droughts have been reported in the last 16 years since 2000. The southern or Eastern Maharashtra (Western India), Andhra Pradesh (Southern coast of India), Northern Karnataka (South-western India), Odisha (Eastern Coast of India), Telangana (Southeastern coast of India) and western Rajasthan are current major drought prone region of India. The frequency of drought is set to increase between 2020 to 2049 years [25].

The south west monsoon was predicted on June-September month in 2013-14. The long period rainfall was evaluated $6 \%$ above deviation. The 184 districts received excess rainfall, 264 districts received normal rainfall, 156 districts received deficient rainfall and 18 districts received scanty rainfall [6]. The meteorological department has been estimated 1 October to 31 December 15 south west monsoon in present period. The long period rainfall was observed 23\% lower. The 62 districts reported excess rainfall, 250 districts reported normal rainfall, 272 districts reported deficient rainfall, 30 districts found scanty rainfall in 2015-16. The global warming has increased the ambient temperature of Biosphere. The increased temperature formed variation in precipitation. The present era of rainfall is declined from precipitation variation. This is generate instability into present and future food grains production.

\section{Water}

Water is significant natural resource to agricultural crops production. The earth surface is covered with 3/4th volume of water. The total volume of water 1385.5 million $\mathrm{km} 3$ is available on earth in which $97.3 \%$ saline water, $2.7 \%$ fresh water, $75.2 \%$ polar ice, $22.6 \%$ ground water, $1.9 \%$ soil moisture and $0.3 \%$ lakes or river water (Figure 16) [26]. The water is available in the Ganga river, Indus river, Yamuna river, Brahmaputra river, parts of Brahmaputra river, Godavari Krishna deltas, Chambal valley and southern river etc in India. The Ganga river is the highest water available among rivers. The canals, rivers, lakes, ponds, canals, wells, tube wells, ground water tanks, rain water harvesting are utilized for irrigation to agriculture activities. The world fresh water of India is $4 \%$ out of $80 \%$ is used in agriculture. India receives 4000 billion cubic meters of precipitation every year in which $48 \%$ precipitation is utilized for ground water and surface bodies. 


\section{Agricultural Research \& Technology: Open Access Journal}

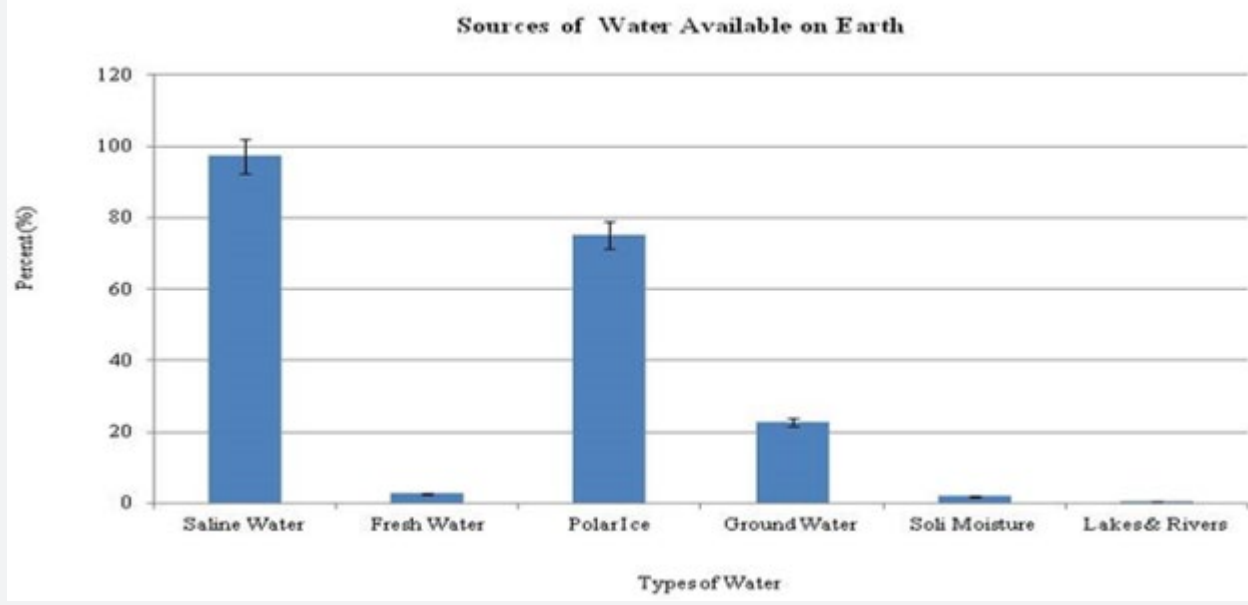

Figure 16: Water sources available on the Earth.
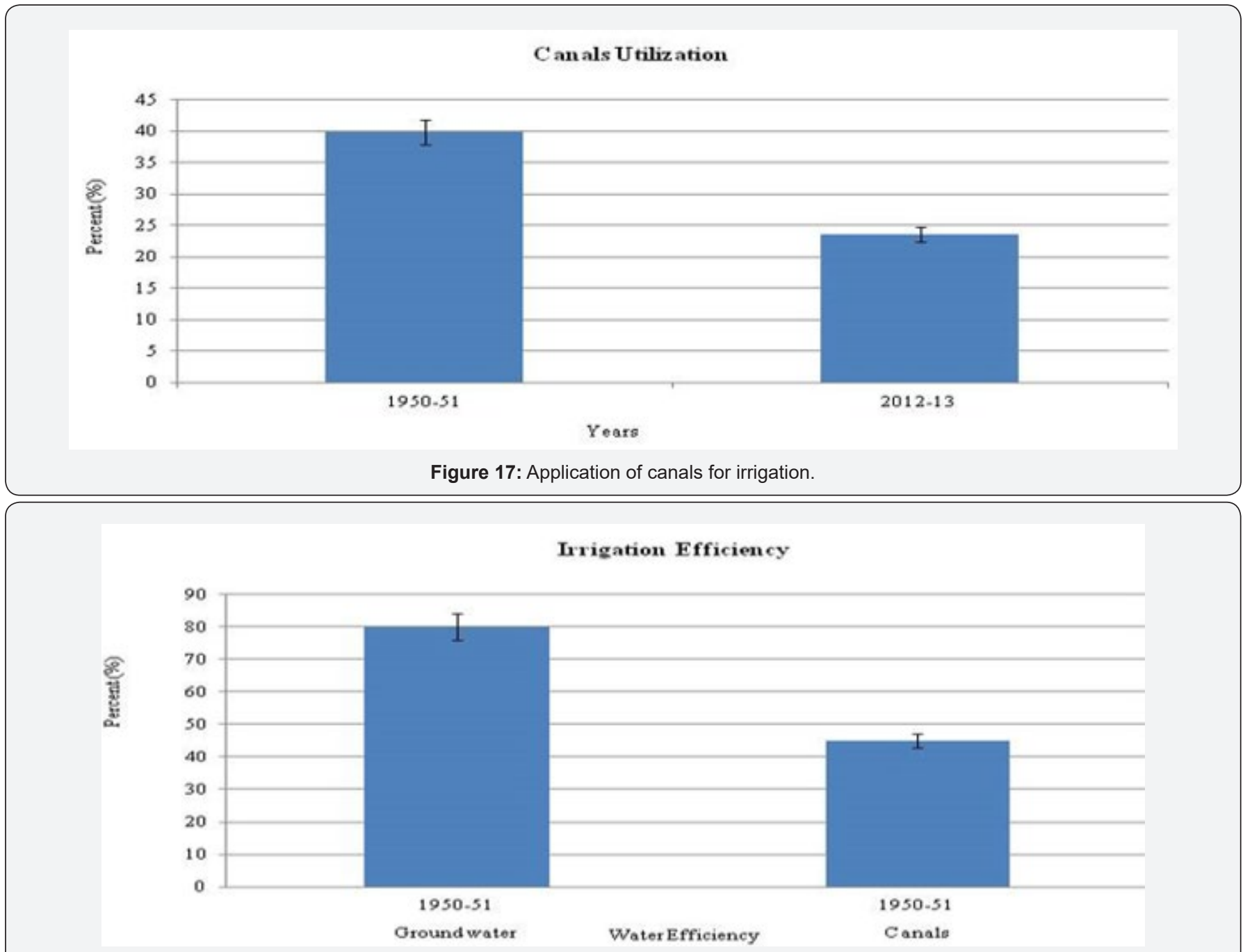

Figure 18: Applications of wells and tube wells for irrigation.

The canals, wells, and tube wells application were more than ground water between 1950-51. The canal irrigated area was $8.3 \mathrm{mha}$ which is now $17 \mathrm{mha}$. The canals utilization has come down from $39.8 \%$ in $1950-51$ to $26 \%$ in $2010-11$ and $39.8 \%$ in
$1950-51$ to $23.6 \%$ in $2012-13$ (Figure 17). The wells and the tube wells were irrigate $29 \%$ area in 1950-51 which is now irrigate $64 \%$ area in 2010-11(Figure 18). The ground water efficiency was 70$80 \%$ in $1950-51$ and the canal efficiency was $25-45 \%$ in $1950-51$ 
(Figure 19). The net cultivable land of is $143.6 \mathrm{mha}$ in which $42 \mathrm{mha}$ is irrigated by ground water and $22 \mathrm{mha}$ is irrigated by canals. So, the ground water utilization has been increased in present period. The total ground water is around 433 billion cubic meters and 398 billion cubic meters is net ground water in which 245 billion cubic meters (62\%) is consumed into irrigation, industrial and domestic activity (Figure 20). 40\% ground water is utilized for irrigation in world and 50\% ground water is utilized for irrigation in India [25]. Uttar Pradesh (80\%), Punjab (70\% of the area irrigated by tube wells and wells) and Uttarakhand (67\%) are the highest utilization of ground water for irrigation in India. The central part of peninsular plateau, Maharashtra (Western India), Kerala coasts, Rajasthan (Aravali Range), Bihar plain (Eastern India), Manipur, Mizoram and Tripura are the lowest utilization of ground water for irrigation due to inappropriate geographical factors. Andaman \& Nicobar Island (Southern India) is $0 \%$ irrigation intensity due to adequate precipitation throughout the year.
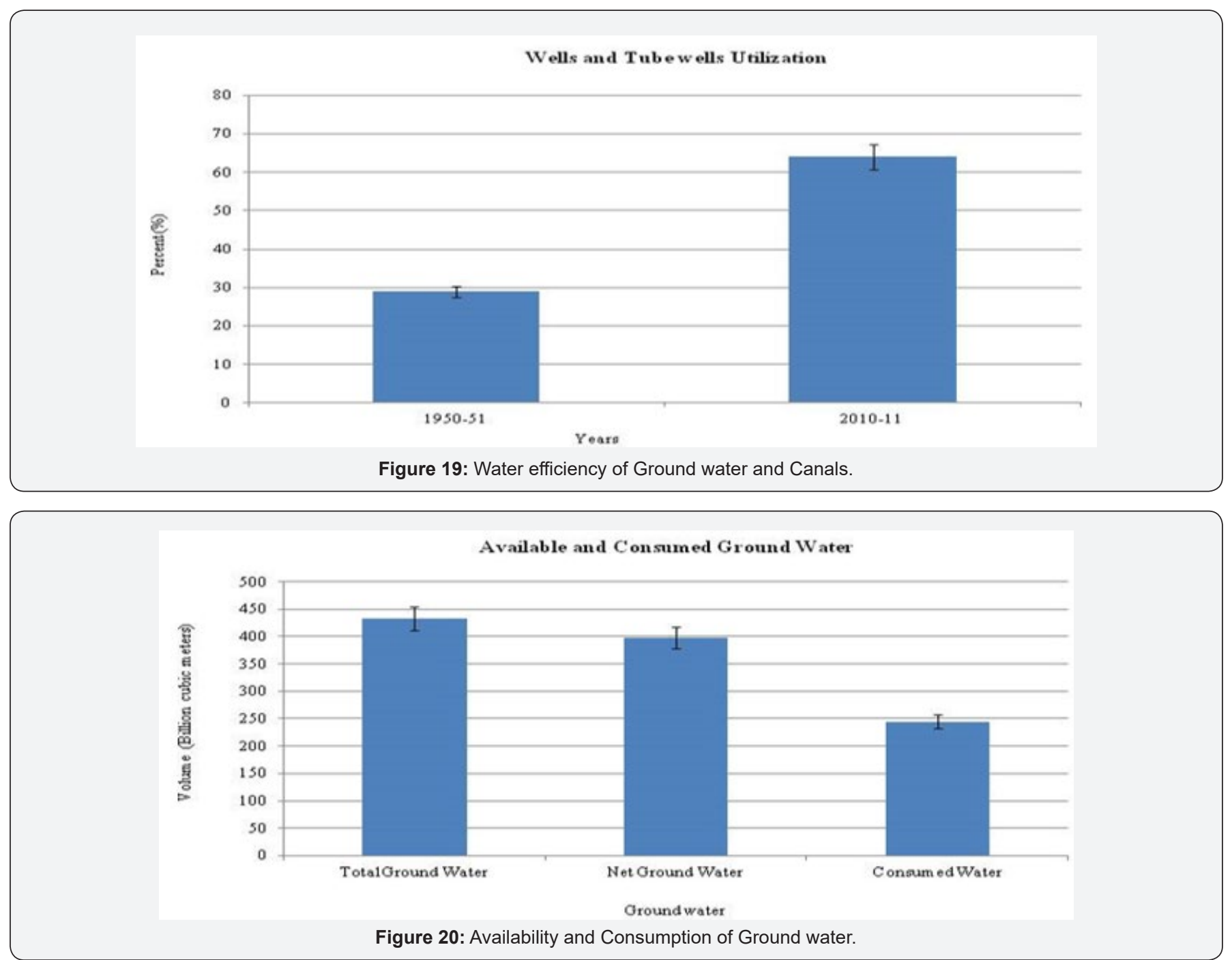

The ground water is depleted because of unsustainable utilization of water resources for irrigation in present period. The ground water level of wells is declined 39\% for long term. The 15 states and the two union territories of ground water level are declined for long term. The districts of south and north interior Karnataka (Southern India), Rayalseema in Andhra Pradesh (Southeastern coast of India), Vidarbha \& Marathwada in Maharashtra (Western India), Western Rajasthan, Bundelkhand region of Uttar Pradesh (Northern India) and Madhya Pradesh (Central India) are state and region where the ground water level has been abated to long term. These states and zones are facing acute water stress. The water table of Latur has gone down by 3.5-
4 meters in 2015-16 and there is no water even 304 meters below the ground. The depletion of ground water is because of climate change and it impacts on production, productivity, crop selection, time of cultivation and irrigation [25].

\section{References}

1. Saurav N, Neeraj A (2014) Supply chain efficiency: an insight from fruits and vegetables sector in India. J Operations and Supply Chain Manage 7(2): 154- 167.

2. Trends in Agricultural Production and Productivity: An Inter-State Comparison. Chapter III. p. 33.

3. (2013) Statistical Yearbook of the Food and Agricultural Organization, FAOSTAT. Agricultural Development Economics Division. p. 1-77. 
4. (2015) Fertilizer consumption (kilograms per hectare of arable land) in India. Trading Economics.

5. Tanvi D (2017) State of Agriculture in India. PRS. pp. 1-29.

6. (2013) Annual Report, 2013-14. Department of agriculture and cooperation, Ministry of Agriculture \& Farmers' Welfare, New Delhi, India, pp. 1-204.

7. (2015) Annual Report, 2015-16. Department of agriculture, cooperation \& farmers' welfare. Ministry of Agriculture \& Farmers' Welfare, New Delhi, India, pp. 1-194.

8. Latha MR, Janaki P (2015) Problem soils and their management. Department of Soil Science and Agricultural Chemistry, Tamil Nadu Agricultural University, Coimbatore, India, pp. 1-46.

9. Nellemann C, Corcoran E, Duarte CM, Valdés L, Young C, et al (2009) Blue Carbon: A Rapid Response Assessment. United Nations Environment Programme, GRID-Arendal.

10. Katyal JC, Chaudhari SK, Dwivedi BS, Biswas DR, Rattan RK, et al. (2006) Soil Health: Concept, Status and Monitoring. Indian Society of Soil Sci 30: 1-107.

11. (2016) Guidelines for Reclamation of Problem Soils- as sub scheme of Rashtriya Krishi Vikas Yojana (RKVY), 2016, Ministry of Agriculture \& Farmers, Welfare Department of Agriculture, Cooperation\& Farmers Welfare, Natural Resource Management Division, New Delhi, India, pp. $1-14$.

12. John TS (1972) Agricultural Implements and Machines in the Collection of the National Museum of History and Technology. Smithsonian Institution Press, City of Washington, USA, pp. 1-68.

13. Abrol IP (2000) Agriculture in India. Centre for Advancement of Sustainable Agriculture. pp. 1-27.

14. Vijay PS, Dinesh J (2011) High-Value Agriculture in India: Past Trends and Future Prospects. Research and Publications, India, pp. 1-51.

15. Saleena EC (2017) Performance Appraisal of Indian Agricultural System with special reference to Agricultural Scenario in the State of Kerala. J Busi Manage 19(10): 5-11.

16. (2016) Statewise and item-wise estimates of value of output from agriculture and allied sectors with new base year (2011-2012), Central statistics office, Ministry of statistics and programme implementation, India, pp. 1-376.

17. Jayaraman T, Kamal M (2018) Climate Change and Agriculture: Current and Future Trends, and Implications for India. Centre for Climate Change and Sustainability Studies, School of Habitat Studies, Tata Institute of Social Sciences, Mumbai, India, pp. 1-19.

18. Easterling DR, Diaz HF, Douglas AV, Hogg WD, Kunkel KE, et al. (1999) Long term observation for monitoring extremes in the Americas. Climatic Change 42: 285-308.

19. (2001) IPCC (Intergovernmental Panel for Climate Change), Climate Change - The Scientific Basis, Contribution of Working Group I to the Third Assessment Report of the Intergovernmental Panel on Climate Change. In: Houghton JT, Ding Y, et al. (Eds.), Cambridge University Press, Cambridge, UK, p. 881.

20. Mall RK, Lal M, Bhatia VS, Rathore LS, Singh R (2004) Mitigating climate change impact on Soybean productivity in India: A simulation study. Agricultural and Forest Meteorology 121(1-2): 113-125.

21. Keeling CD, Whorf TP, Wahlen MM, Van der PJ (1995) Interannual extreames in the rate of rise of atmosphric carbon dioxide since 1980. Nature 375: 666-670.

22. Lal M, Nozawa T, Emori S, Harasawa H, Takahashi K, et al. (2001) Future climate change: Implications for Indian summer monsoon and its variability. Curr Sci 81(9): 1196-1207.

23. Goswami BN, Venugopal V, Sengupta D, Madhusoodanan MS, Xavier PK (2006) Increasing Trend of Extreme Rain Events over India in a Warming Environment. Sci 314(5804): 1442-1445.

24. Mall RK, Ranjeet S, Akhilesh G, Srinivasan G, Rathore LS (2006) Impact of climate change on Indian agriculture: A review. Climatic Change 78: 445-478.

25. Vibha D (2017) Water and Agriculture in India: Background paper for the South Asia expert panel during the Global Forum for Food and Agriculture. Federal Ministry of Food and Agriculture. pp. 1-28.

26. Panjab S (2004) Indian Agricultural Development in Changing Scenario Past, Present and Future. J Ind Soci Agril b Stat pp. 1-13.

\begin{tabular}{l} 
Your next submission with Juniper Publishers \\
will reach you the below assets \\
- Quality Editorial service \\
- Swift Peer Review \\
- Reprints availability \\
- E-prints Service \\
- Manuscript Podcast for convenient understanding \\
- Global attainment for your research \\
- Manuscript accessibility in different formats \\
( Pdf, E-pub, Full Text, Audio) \\
- Unceasing customer service \\
Track the below URL for one-step submission \\
https://juniperpublishers.com/online-submission.php \\
\hline
\end{tabular}

